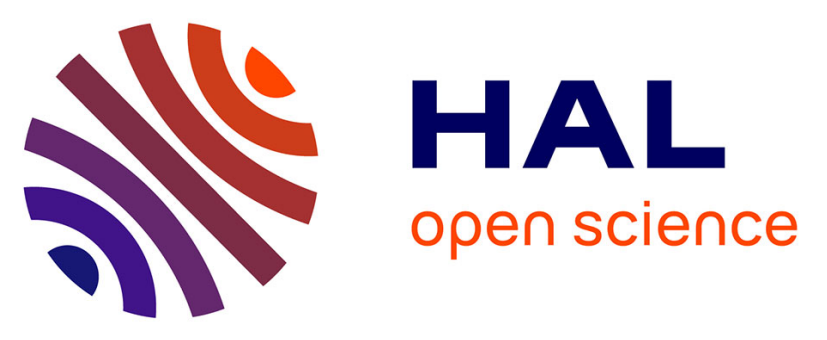

\title{
Assessment of the Impact of Dams on River Regimes, Sediment Transports to the Sea, and Coastal Changes
}

Gil Mahe, Oula Amrouni, Thouraya Ben Moussa, Laurent Dezileau, Rajae El Aoula, Hamadi Habaieb, Abderraouf Hzami, Ilias Kacimi, Abderrahmane Khedimallah, Fatma Kotti, et al.

\section{- To cite this version:}

Gil Mahe, Oula Amrouni, Thouraya Ben Moussa, Laurent Dezileau, Rajae El Aoula, et al.. Assessment of the Impact of Dams on River Regimes, Sediment Transports to the Sea, and Coastal Changes. Kallel A.; Ksibi M.; Ben Dhia H.; Khélifi N. Recent Advances in Environmental Science from the Euro-Mediterranean and Surrounding Regions. EMCEI, Springer, pp.31-32, 2018, 10.1007/978-3319-70548-4_12 . hal-01861450

\section{HAL Id: hal-01861450 https://hal.science/hal-01861450}

Submitted on 11 Dec 2019

HAL is a multi-disciplinary open access archive for the deposit and dissemination of scientific research documents, whether they are published or not. The documents may come from teaching and research institutions in France or abroad, or from public or private research centers.
L'archive ouverte pluridisciplinaire HAL, est destinée au dépôt et à la diffusion de documents scientifiques de niveau recherche, publiés ou non, émanant des établissements d'enseignement et de recherche français ou étrangers, des laboratoires publics ou privés. 


\title{
Assessment of the Impact of Dams on River Regimes, Sediment Transports to the Sea, and Coastal Changes
}

\author{
Gil Mahe, Oula Amrouni, Thouraya Ben Moussa, Laurent Dezileau, Rajae El Aoula, Hamadi \\ Habaieb, Abderraouf Hzami, Ilias Kacimi, Abderrahmane Khedimallah, Fatma Kotti, Mohamed \\ Meddi, Nadia Mhammdi, and Saadi Abdeljaouad
}

\author{
Keywords \\ Rivers • North Africa • Dams • Sediment transport • Coastal morphological changes \\ Sands
}

A great number of rivers of North Africa are equipped with many dams for multiple purposes, mainly potable water, irrigation and energy production. In most of the countriesMorocco, Algeria and Tunisia, the storage capacity exceeds the runoff capacity, which means that water is stored several times in a row during its course to the sea. This leads to the storage of massive amounts of sediments into the dams' lakes, but nothing is known about how much sediment is released from these dams. This topic is mainly unstudied by the regional scientists due to lack of measurements of sediment transport, or poor access to observed data when available. Thus there are no time series of sediment loads to the sea from the North African rivers. One of the conse-

G. Mahe

IRD, UMR HSM, Montpellier University, Montpellier, France e-mail: gil.mahe@ird.fr

O. Amrouni · A. Hzami

INSTM, Salammbo, Tunisia

e-mail: oulabz@yahoo.fr

A. Hzami

e-mail: abderraoufhzami@gmail.com

T. B. Moussa $(\square)$

FST /INSTM, Salammbo, Tunisia

e-mail: benmoussa.thouraya87@gmail.com

L. Dezileau

Geosciences Laboratory, University of Montpellier, Montpellier,

France

e-mail: dezileau@gm.univ-montp2.fr

R. El Aoula · N. Mhammdi

Institut Scientifique, University Mohammed V, Rabat, Morocco e-mail: elaoula.rajae@gmail.com quences is that it is impossible to relate recently observed coastal morphological changes to changes in the sediment recharge from the continent. This study brings a synthesis of recent works on this topic over the largest rivers of North Africa in the three countries. In Morocco and Tunisia there no continuous time series of sediment transport observations. There we sampled sediment cores in river meanders, to draw the history of real sediment exportations to the sea, on the basis of granulometry, geochemical and isotopic studies. Only in Algeria are there observations of sediment transport at main hydrological stations. The times series show many lack of data which are reconstructed according to runoff/concentrations correlations, taking seasonal factor
N. Mhammdi

e-mail: nmhammdif@yahoo.com

H. Habaieb

INRGREF, Ariana, Tunisia

e-mail: habaieb.hamadi@yahoo.fr

I. Kacimi

Faculty of Sciences, University Mohammed V, Rabat, Morocco e-mail: iliaskacimi@yahoo.fr

A. Khedimallah · M. Meddi

ENSH, Blida, Algeria

e-mail: a.khedimallah@ensh.dz

M. Meddi

e-mail: mmeddi@yahoo.fr

F. Kotti

INAT, Tunis, Tunisia

e-mail: f.kotti@yahoo.fr

S. Abdeljaouad

Faculty of Sciences, University of Tunis El Manar, Tunis, Tunisia

e-mail: saadi_abdeljaouad@yahoo.fr 
into account. Methodologies and first results are shown in this study. They reflect the huge decrease of the sediment transport to the sea over time since several decades, and in the case of the Medjerda river in Tunisia, the absence of sands in the river sediments since 34 years and the construction of the major dam on the main stream.

\section{Author Biography}

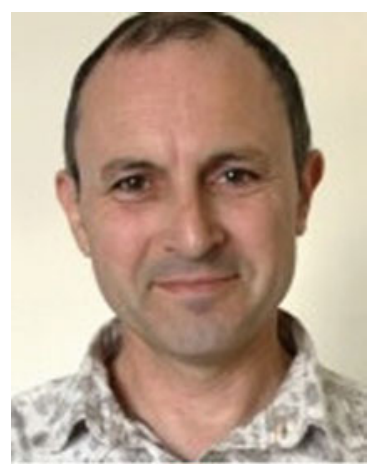

Dr. Gil Mahe Research Director at the Institut de Recherche pour le Développement (IRD). He is an hydroclimatologist specialized on West and Central Africa and Maghreb, Ph.D. of the Faculty of Sciences of Paris XI, on the topic of African discharges to the ocean and links with climate and ocean variability, and HDR of the Montpellier University on the topic of Relationships between man, environment and water resources in Africa and climate change. $\mathrm{He}$ received the "Georges Hachette Award" from the Société de Géographie de Paris for his Ph.D. work published by ORSTOM. He is responsible for the FRIEND program UNESCO. International Hydrological Program, and coordinator of the MEDFRIEND program for the Mediterranean. He is the President of the International Commission of Surface Water of the International Association of Hydrological Sciences, and member of the Scientific Commission of the International Sediment Initiative and of the Large River Initiative (UNESCO). $\mathrm{He}$ is member of the pedagogical team of the Master GOES of the University Mohammed V of Rabat, and associate member of the Research Center on "Water, Natural Resources, Environment and Sustainable Development" of the University of Rabat. He is responsible for two research programs in Tunisia PHC/RYSCMED and in Morocco PHC/CASBA. He also participates in two research programs in Algeria and in Gabon/Congo. He has been elected member of the Specialists Commission no 36 at the University of Montpellier, and spent 13 years at IRD Specialists or partnership Commissions. He has been for 5 years team leader of the Water team of the IGCP/International Geological Program of UNESCO, and he is member of the Scientific Commission of the program "Abandonned Mines" of IGCP/Swedish funds. He has been member of the UNESCO expert group on the impact of land cover changes on hydrological regimes. He has been a 6-year Associated Editor of Hydrological Sciences Journal, and he is currently Associate Editor of Ecohydrology and Hydrobiology/Elsevier and of «Climatologie» AIC journal. He is responsible for the conference cycle on the "hydrology of African Large river basins" UNESCO/IAHS, started in 2015, and scientific editor of numerous special issues of journals and books. He is teaching since several years in Maghreb Universities and High Schools an initiation to bibliometry, to master and doctorate students and researchers. 